\title{
Review \\ Business Incubators, Accelerators, and Performance of Technology-Based Ventures: A Systematic Literature Review
}

\author{
João Leitão ${ }^{1,2,3,4, *(\mathbb{C})}$, Dina Pereira ${ }^{2,3}$ (i) and Ângela Gonçalves ${ }^{2}$ (1) \\ 1 NECE-Research Unit in Business Sciences, Faculty of Human and Social Sciences, University of Beira \\ Interior (UBI), Estrada do Sineiro, 6200-001 Covilhã, Portugal \\ 2 Research Unit in Business Sciences (NECE), University of Beira Interior, 6200-209 Covilhã, Portugal; \\ dina@ubi.pt (D.P.); angela.goncalves@ubi.pt (Â.G.) \\ 3 Centre for Management Studies of Instituto Superior Técnico (CEG-IST), University of Lisbon, \\ 1649-004 Lisboa, Portugal \\ 4 Instituto de Ciências Sociais (ICS), University of Lisbon, 1649-004 Lisboa, Portugal \\ * Correspondence: jleitao@ubi.pt
}

check for updates

Citation: Leitão, J.; Pereira, D.; Gonçalves, Â. Business Incubators, Accelerators, and Performance of Technology-Based Ventures: A Systematic Literature Review. J. Open Innov. Technol. Mark. Complex. 2022, 8, 46. https://doi.org/10.3390/ joitmc 8010046

Received: 18 January 2022 Accepted: 24 February 2022 Published: 1 March 2022

Publisher's Note: MDPI stays neutral with regard to jurisdictional claims in published maps and institutional affiliations.

Copyright: (C) 2022 by the authors. Licensee MDPI, Basel, Switzerland. This article is an open access article distributed under the terms and conditions of the Creative Commons Attribution (CC BY) license (https:// creativecommons.org/licenses/by/ $4.0 /)$.

\begin{abstract}
This review aims to identify the typologies of business incubators (BI) and business accelerators (BA) and to define a taxonomy integrating both the BI's and BA's characteristics and services portfolio, facilitating the adoption of open innovation practices. A systematic literature review (SLR) was carried out encompassing the research topic concerning the relationship between the incubation structures and the performance of technology-based ventures. This comprehensive SLR encompasses a total of 1614 publications, aiming to advance the knowledge on BI and BA. This SLR allowed for the identification of current trends and future challenges, as well as of the most important authors, publications, and journals in this research framework. This SLR establishes a new taxonomy for BI and BA, based upon three main pillars: human capital, social capital, and organizational capital. BI and BA help in the development of new high-technology ventures, by being facilitators for open innovation practices. This SLR is limited by the literature, as the collection of publications was performed exclusively through ISI Web of Science (WoS). Further research can be made into the modes of how these structures impact open innovation practices at the regional level using a knowledge spillover approach.
\end{abstract}

Keywords: accelerators; business development; firm growth; incubators; start-ups

\section{Introduction}

Considering the turbulence existent in the entrepreneurial process of creation, survival, the management of new technology based ventures, and the increasingly important role played by both business incubators (BI) and business accelerators (BA), there is a need to better understand the portfolio of services supplied by this type of support structures and the needs of the companies that demand for a set of diversified services, which are not easily represented and typified in the reference literature.

Business incubation is the most effective way of assisting entrepreneurs in their new venture creation [1]. BI are oftentimes viewed as drivers of job creation and thus regional economic development as they provide several facilities [2] ranging from office space and capital to management support and knowledge [3]. BI have evolved in terms of types, variety, stakeholders, sponsors, location, goals, and services offered [4]. BI constitute an important dimension in the innovation system [3] and have become part of modern entrepreneurial ecosystems [5]. They are, as a result, sprouting everywhere in developed as well as rapidly developing countries [6]. The success of BI depend on them attracting the best incubated ventures, and their ability to produce new firms, with high growth potential, spurring from R\&D developed in universities and research institutions [7]. 
BA can be defined as organizations that help nascent ventures get a jumpstart by providing them with funds and resources [8], seed capital and sometimes even working space; helping ventures to define and build their own products/services; arranging for customers; and securing capital, investors, and employees [9]. BA programs can be more effective, and even avoid failure when the teams are willing to have an open innovation attitude [10].

A startup is a new venture that entails the development and validation of a business model [11]. Startup performance can be affected by material capital, human capital, knowledge, and entrepreneurial capital [12]. Startup performance can also be affected by the access to multiple networks, resources and knowledge [10]. Furthermore, open innovation practices facilitate network creation, relationships for collaborative work and knowledge flow, partnerships and external links to other networks and firms [13]. In terms of the research gap found in the literature, it remains to be understood how BI and BA structures can be facilitators for the adoption of open innovation practices.

This systematic literature review (SLR) aims to define a representative taxonomy, which can be useful for entrepreneurs demanding a portfolio of incubation services (which are supplied by this type of supportive structures), and to identify how can BI and BA facilitate open innovation practices. In addition, it aims to advance the still limited knowledge about the modes of how incubation and acceleration ecosystems influence the performance of technology-based ventures along their life cycle, facilitating the adoption of open innovation practices. This study, therefore, addresses these gaps.

The remainder of this review is structured as follows. Firstly, the theoretical framework and main and secondary research questions are developed, and presented. Secondly, the methodological design of the present study is detailed. Thirdly, the results and discussion are presented. Fourthly, the conclusions and future research avenues are laid out.

\section{Theoretical Framework and Research Questions}

BI appeared in the late 1950s, and from then on there have been innumerous definitions for the term [14-18], whereas BA appeared latter (in 2005). The definitions for BA are fewer, but nonetheless various exist $[8,9,19]$.

BI can be defined as organizations that provide support to new businesses during a period of time, either through tangible assets (for example, space and administrative services), or through intangible ones (for example, knowledge and access to networks) [5].

The majority of the literature regarding BI mainly discuss incubators that do not restrict to specific sectors. A study from Germany found that from 1999 to 2008, a third of all new incubators created were specialized incubators, specializing in one or a few complementary sectors [19]. Not all requirements of a BI and specialized BI differ, nonetheless, emerging from a sector specific focus can have its benefits, mainly the potential availability of specialized equipment and structures, sector specific knowledge of the specialized BI staff, fruitful networking and availability for synergies between the incubatees [19].

The entrepreneurship education offered by universities has the capacity to motivate and attract graduates to engage in entrepreneurial ventures, and these graduates can be a source of nascent entrepreneurship [20]. BI associated with universities, enable technology transfer and empower the networks that allow for technology to be materialized into new ventures [21].

By virtue of the success of BI, later came business accelerators (BA) as an evolution of the BI models [22]. BA were idealized as an arrangement of five main features: (1) standardized seed funding packages; (2) cohort-based entry and exit; (3) a structured capacity development programme; (4) mentoring; and (5) physical co-location [23]. BA can be defined as cohort-based programs of fixed duration for startups. These programs can entail educational components, as well as mentorship moments, which come to a conclusion in a final event [24]. Most BA offer an initial seed investment in exchange for services and space [23] and target a specific sector, such as manufacturing, health care, IT [25], 
biotechnology, or telecommunications [26], while others have a horizontal perspective focusing instead on the region [27].

Y Combinator, the first accelerator, was launched in 2005. Since then, the popularity of BA has been boosted mainly thanks to participants such as Dropbox, Reddit, and Airbnb. Another pioneer BA, Techstars was founded in 2007, the two BA combined have accelerated over 2000 startups [24]. Currently there are at least two hundred accelerators worldwide and their portfolio companies have raised more than $\$ 14.5$ billion in funding [28].

Both BI and BA are important resources that aid the growth of entrepreneurial endeavors. Nonetheless, looking at the various definitions for the two, there are some factors that distinguish them. One of the factors of distinction between the two structures is that BI provide space for the company to grow, while BA either do not provide space, or provide some type of co-working space or desk space [24]. Another key distinguishing aspect is that BA assign funding to their participants, while BI do not. Duration of the program is also another distinguishing factor, as BI programs last for varying timeframes and include forms of mentorship and support which serve as aids for the business to get off the ground, what sometimes can take years. On the other hand, a BA program usually lasts from three to six months. BA programs focus on rapid growth, and strategies for organizational and operational difficulties which the business might be facing or will face.

BI and BA both aim to create entrepreneurial ecosystems. The term "ecosystem" was introduced to describe the community in Silicon Valley, showing that entrepreneurship oftentimes depends on a nurturing environment for emerging businesses [29]. An entrepreneurial ecosystem mainly refers to a group of interacting firms that depend on each other's activities [30]. A better understanding of the boundaries of the ecosystem is essential in order to evaluate the performance, outputs, and impact of that ecosystem [31].

Through an extensive SLR on entrepreneurial ecosystems, the terms: "innovation", "clusters", and "open innovation"; were identified as the three most relevant characteristics for entrepreneurial ecosystems, influencing a new definition for this complex concept, where these are identified as an environment where entrepreneurship can flourish, aided by an ensemble of various independent players and factors [32]. In a "closed innovation" model, a company does not search for ideas and knowledge form outside its boundaries, but instead the company generates, develops, and markets its own knowledge [33]. However, a startup's success can depend on external knowledge flows [10]. That gave rise to a shift in the paradigm [34], from closed to "open innovation", being the sharing of ideas and knowledge from outside a firm into the inside [33] and this type of practice should be endorsed in entrepreneurial ecosystems [13].

Structures such as incubators and accelerators provide opportunities for knowledge transfer, experience sharing, and cooperation, as the different incubated ventures share a common physical location [35]. These structures play a critical role in fostering the economic development of the regions [36], as these structures can host entrepreneurial ecosystems [37]. A recent study found that open innovation practices with the goal of developing an entrepreneurial ecosystem facilitate network creation, relationships for collaborative work and knowledge flow, and partnerships and external links to other networks and firms [13]. Since the introduction of this concept, the organizations have opened their research and development processes [38]. There are two pathways for open innovation practices: inbound-integrating into the organization, and outbound-transferring from the organization to the outside.

The literature concerning BI and BA has been evolving. Nonetheless, the question of how these structures can facilitate network creation, foster partnerships and knowledge flow, thus acting as facilitators for open innovation practices, still remains unanswered. It is expected that these structures play a role in the stage of open innovation, but very few information is available [39]. Moreover, another question arises: what services provided by $\mathrm{BI}$ and BA are oriented for open innovation practices in the two pathways (inbound (from the university to an external environment) and outbound (from an external environment to 
the university)? In line with the open debate [34], new review studies are needed in order to broaden the literature covering this subject.

Taking into account the abovementioned research, this SLR aims to address the following main research question (MRQ):

MRQ: How incubation and acceleration ecosystems foster the adoption of open innovation practices influencing the performance of technology-based ventures along their life cycle?

For better understanding, defining and identifying the most relevant streams of the literature focused on the performance of incubatee startups along their life-cycle, the following secondary research questions (SRQ) were formulated:

SRQ1: Does the specialization of incubation and acceleration ecosystems facilitates the adoption of open innovation practices influencing the performance of technology-based ventures along their life cycle?

SRQ2: What are the types of capital related with the adoption of open innovation practices influencing the performance of technology-based ventures along their life cycle?

SRQ3: What are the research gaps in the literature concerning incubation and acceleration ecosystems, facilitators of open innovation practices, and technology-based ventures performance?

\section{Methodological Design}

SLRs have become more popular in recent times, especially in the field of entrepreneurship [32,40-43]. The methodology of SLRs has evolved and has become more precise mainly due to the evolution of technology and the existence of electronic databases. SLRs differ from traditional literature reviews as the former have a higher degree of objectivity and transparency [44] and allow for a more detailed and careful examination of the existing literature and the construction of solid definitions and even routes for further research [41]. The main objective of a literature review is to summarize the existing knowledge about a certain topic or streams of the literature [45]. Non-systematic literature reviews can be biased and subjective [46] since they lack a systematic process, can use unrepresentative samples of literature [47], and do not necessarily gauge the quality of the publications used [41]. A SLR follows a pre-defined procedure to analyze literature and ranking it according to its quality [44]. A SLR can be defined as a methodic review of the literature that is performed with objectivity and can be replicated [41]. The SLR method is used here to evaluate the state of the art of the research topic under analysis.

For the literature identification in this SLR, a search was performed in the Web of Science (WOS) database in June 2021. WOS was used as it is a multidisciplinary database and includes indexed journals. Furthermore, this database delivers information in regards to the documents cited [48], the documents citing each publication and funding acknowledgment [49].

For building the database used in the research, several phases were fulfilled (see Figure 1). In the first phase of this analysis, articles or reviews with the following expressions were selected: Incubator, Accelerator, Technology-Based Ventures, Science and Tech Parks, Science and Technology Parks, Innovative Ecosystem, Intellectual Capital, Human Capital, Social Capital, Organizational Capital, Social Performance, Innovative Performance, Technology Entrepreneurship, Technology Ventures, Techno-entrepreneurship, Ecosystem Specialization, Ecosystem Diversification, Technological Intensity, Startup Life Cycle. Firstly, the initial search for the abovementioned terms returned 142.559 results. On phase 2, the search was limited to only documents in the English language, the results were also filtered by areas of research of interest for the subject matter of this SLR, being: Business, Business finance, Economics, Engineering Industrial, Management, Regional Urban Planning, Social Sciences Interdisciplinary, and Urban Studies. This search returned 29.189 results. Afterwards, on phase 3 , the results were limited to "article" or "review documents", omitting books and book chapters, since articles and reviews can be considered validated knowledge and can have the most impact on the area of research interest [50-53], which returned 
22.900 results. The timeframe of the search was limited to results from 2005 to June 2021 limiting the final set to 18.905 results.

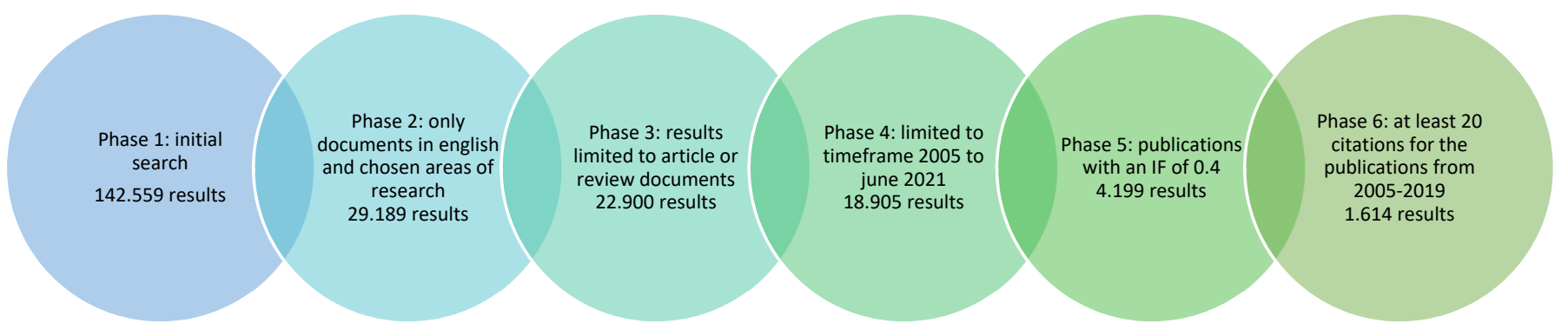

Figure 1. Phases for building the database (Source: own elaboration).

As the quality of a SLR depends on the quality and validity of the publications considered, at phase 4 , documents with an impact factor inferior to 0.4 were removed, as this allows for the assessment of the influence of a specific publication [48,54]. Still in phase 4 , the publications with no relation to the research topic (based on the reading of the title, abstract, and if needed, the whole article) were removed, reducing the sample to 4.199 publications and totaling 128.525 citations. A database was created in order to arrange the important information of each publication.

Inspired by the methodological design adopted by [32], due to the number of publications found and in order to achieve quality in this SLR, only publications with more than 20 citations were chosen, from 2005 to 2019. For the years of 2020 and 2021, as these are the most recent publications and have not reached more than 20 citations, the previous criteria were not used. Ultimately, 1446 publications were collected from the timeframe of 2005 to 2019, and 168 articles were collected from the years of 2020 and 2021. After all of these steps, the final number of 1614 publications was attained.

The attributes present in the database created for this SLR are: Title of the Publication, Author, Source Journal, Impact Factor of the Source Journal, Year of Publication, and Number of Citations. When the publications were not available for consultation or download in WoS, other databases were used, such as Emerald, ResearchGate, and Google Scholar. The criteria for inclusion and exclusion are presented below in Table 1.

Table 1. Inclusion and exclusion criteria (Source: Own elaboration).

\begin{tabular}{cc}
\hline Inclusion & Exclusion \\
\hline Indexed in WoS & $\begin{array}{c}\text { Books, Book Chapters, conference } \\
\text { reports, proceedings papers }\end{array}$ \\
\hline Publications in English & $\begin{array}{c}\text { Publication in languages other } \\
\text { than English }\end{array}$ \\
\hline Article or Review & \\
\hline $\begin{array}{c}\text { WoS Categories: management; business; industrial } \\
\text { social sciences interdisciplinary; regional urban planning }\end{array}$ & \\
\hline Publication in the 2005-2021 period \\
\hline Journals with an impact factor equal to or above 0.40 \\
\hline Publications from the 2005-2019 cohort, having a \\
minimum of 20 citations
\end{tabular}

\section{Results and Discussion}

To better assess the ongoing academic debate devoted to the research topic on the structures of incubation and acceleration and the performance of technology-based ven- 
tures, the evolution of the number of publications, the most cited publications and the leading journals will be identified in this section.

\subsection{Descriptive Analysis}

Analyzing the 1614 publications and their distribution in time (see Figure 2), we can observe that the total number of articles has been increasing, having a higher increase rate from 2019 to 2020 (around 700\%). It is also possible to attest that the citations have been keeping up with the trend of a higher publishing and increasing since 2005. The greatest number of publications on this subject occurred in 2020, with a total of 145 published articles. In Figure 2, it is worthwhile to note that the publications concerning the last year, 2021, represent only six months of the year. It is worthy of note that for the last two years, 2020 and 2021, the expected total number of citations was forecasted by making use of the simple exponential smoothing method, including the mean value and trend for the reference sampling in the 2009-2019 period.

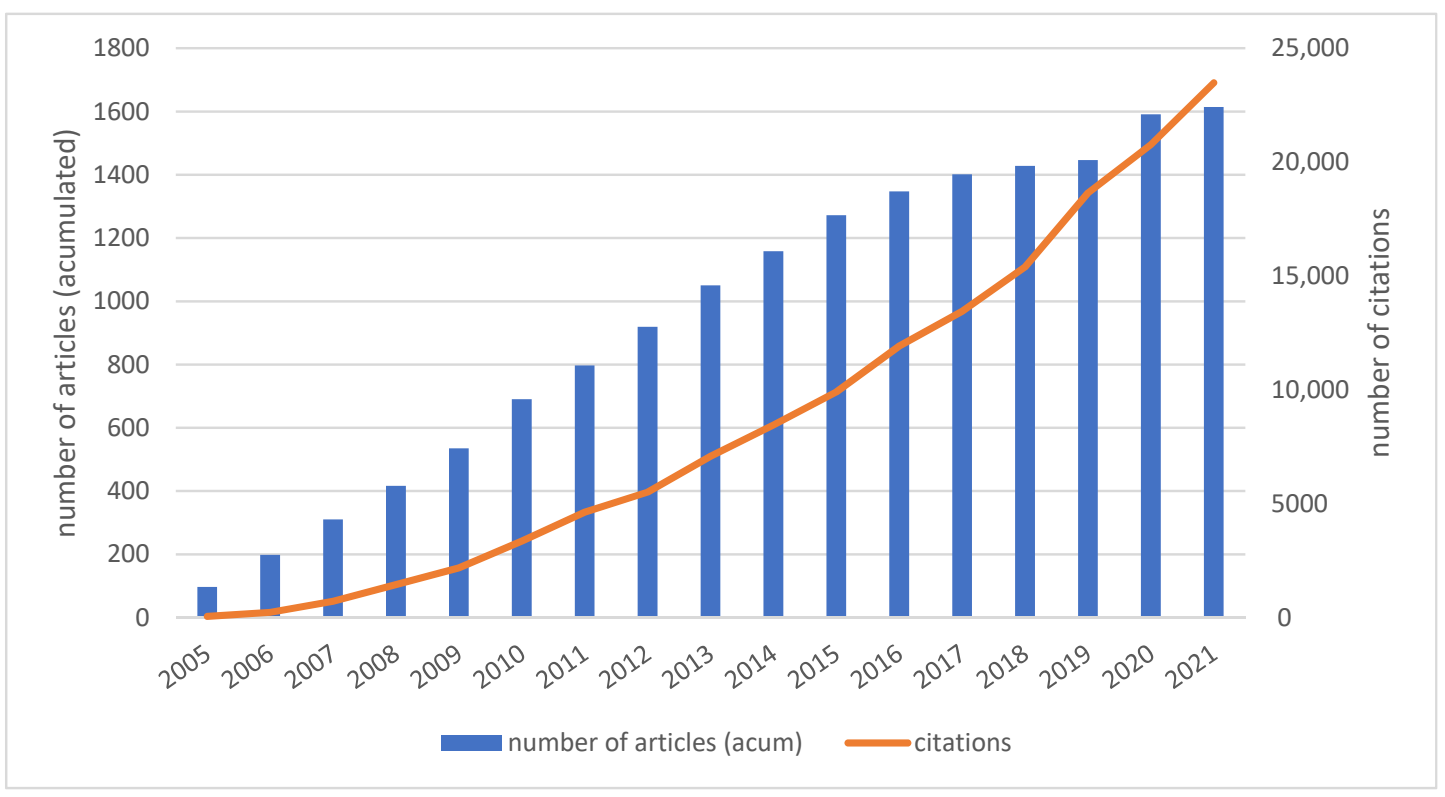

Figure 2. Publications and citations (Source: Own elaboration).

The 1614 publications span across 208 journals. Examining the journal representativeness, it is possible to see in Figure 3 that the most prominent journal is "Research Policy" with 95 publications present in this study. The following most prominent journals are: "Small Business Economics", "Entrepreneurship Theory and Practice", "Technovation", "Strategic Management Journal", "Journal of Business Venturing", "International Journal of Human Resource Management", "Technological Forecasting and Social Change”, "Journal of Technology Transfer", and finally "Entrepreneurship and Regional Development".

In order to provide an accurate representation of the number of times an article is cited by other publications, a citation analysis is presented, using the VOSViewer software [55]. This analysis started with the 1614 publications, and the original sample was reduced to documents that were cited at least 30 times, reaching a number of 1012 documents, of which 1000 were gathered in the final sample. In Figure 4, the cited documents can be visualized. The larger nodes represent the most cited articles, as the larger the node, the more citations that specific document has. Also, the relatedness of the publications can be visualized, as the closer two nodes are, the greater the number of times those publications cite each other. The article with the higher number of citations (2379), was published in the Strategic Management Journal in 2006, by Laursen and Salter [56]. To better identify the most cited documents, the top 10 most cited publications are presented in Table 2 . This 
way, the most prominent publications can be identified [57], as well as the main nodes and relative importance of the highly cited works (see Figure 4).

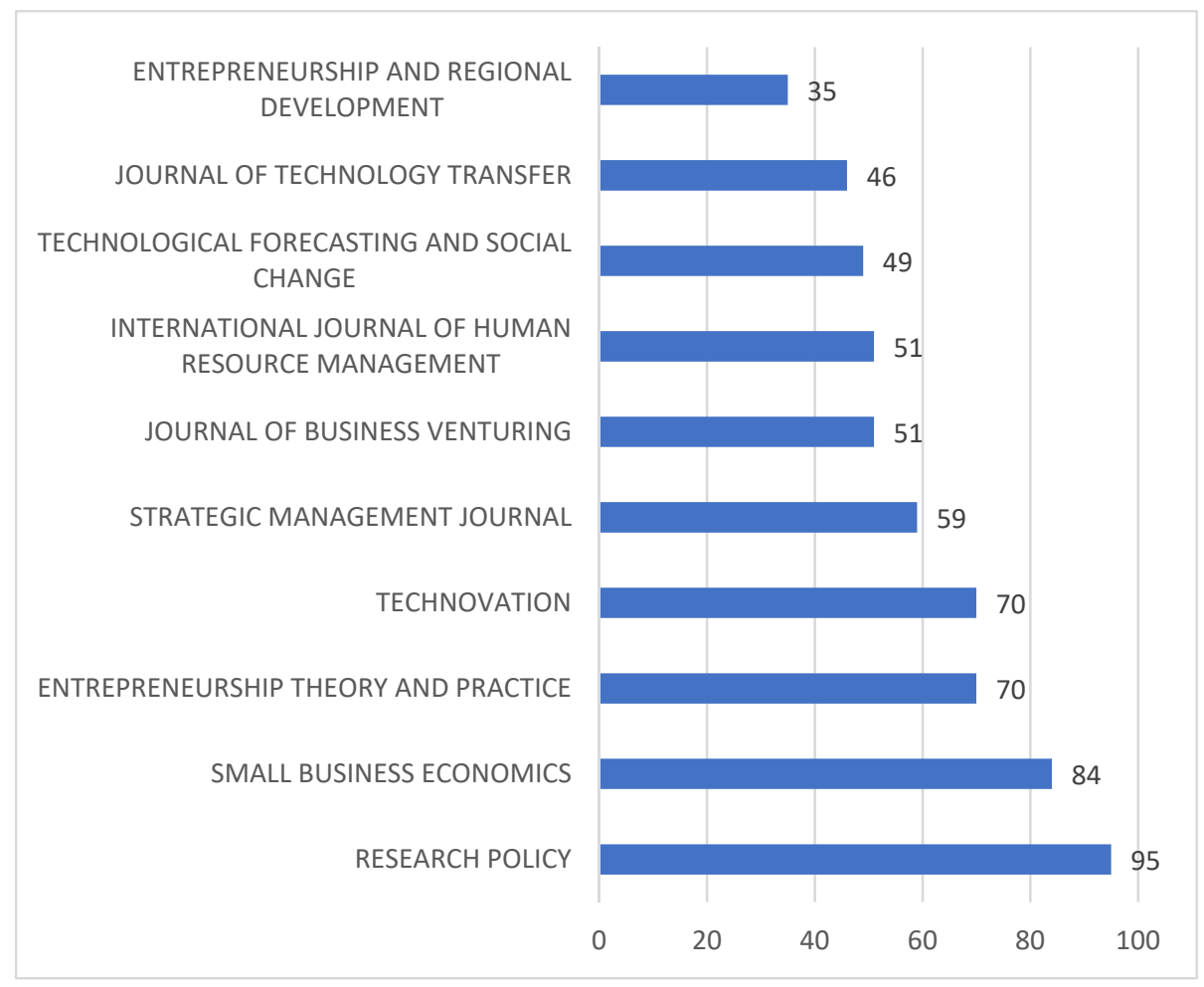

Figure 3. Number of publications per journal, top ten (Source: Own elaboration).

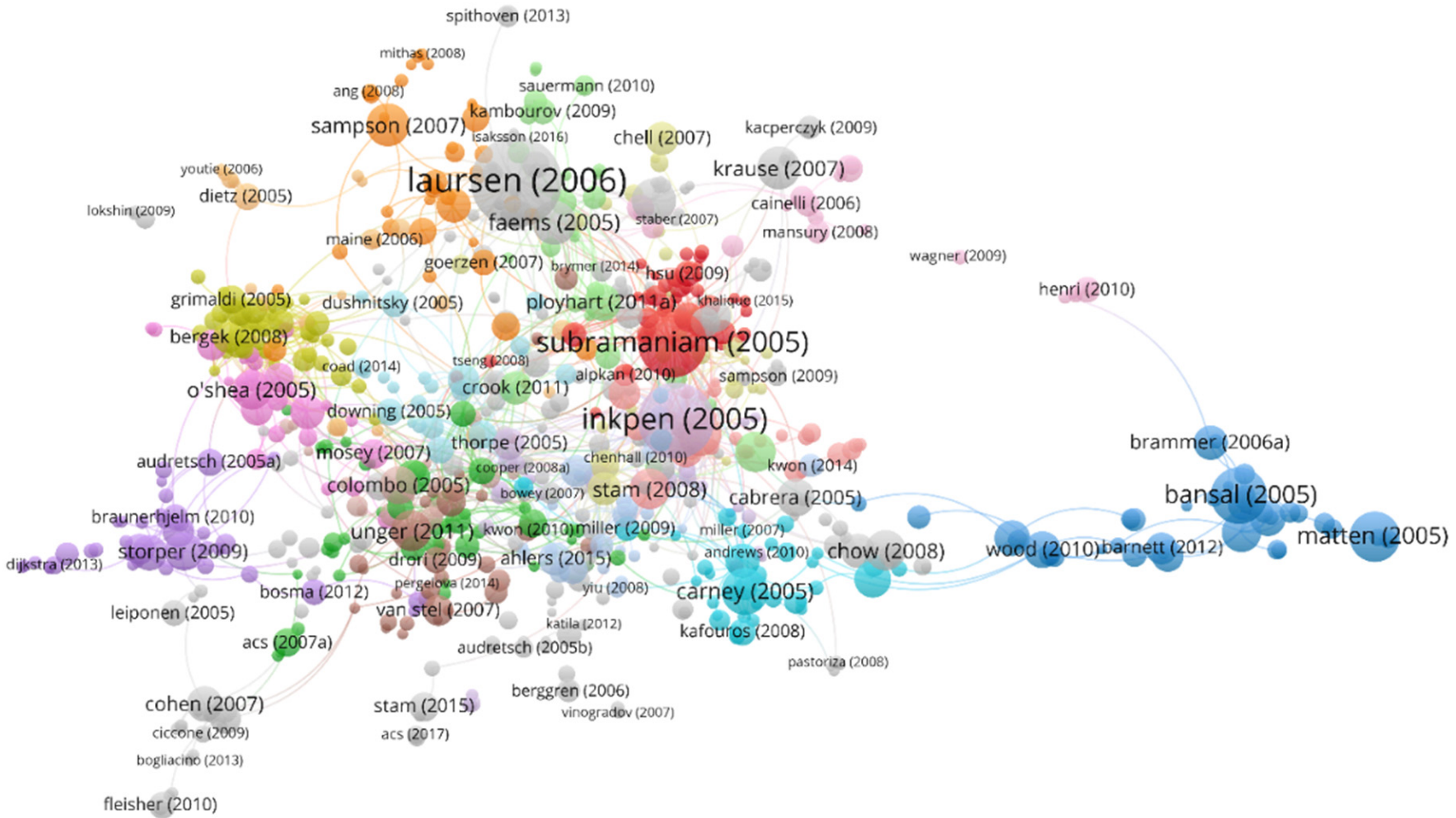

Figure 4. Most cited publications on the research topic: the structures of incubation and acceleration and the performance of technology-based ventures. (Source: Own elaboration using the VOSviewer software). 
Table 2. Top 10 publications (Source: Own elaboration).

\begin{tabular}{|c|c|c|c|c|}
\hline Title of the Publication & Authors & Journal & Year & Citations \\
\hline $\begin{array}{l}\text { Open for innovation: The role of openness in } \\
\text { explaining innovation performance among } \\
\text { UK manufacturing firms }\end{array}$ & Laursen, K; Salter, A [56] & $\begin{array}{l}\text { Strategic Management } \\
\text { Journal }\end{array}$ & 2006 & 2379 \\
\hline $\begin{array}{l}\text { Social capital, networks, and } \\
\text { knowledge transfer }\end{array}$ & Inkpen, AC; Tsang, EWK [58] & $\begin{array}{c}\text { Academy of } \\
\text { Management Review }\end{array}$ & 2005 & 1634 \\
\hline $\begin{array}{l}\text { The influence of intellectual capital on the } \\
\text { types of innovative capabilities }\end{array}$ & $\begin{array}{l}\text { Subramaniam, M; Youndt, } \\
\text { MA [59] }\end{array}$ & $\begin{array}{c}\text { Academy of } \\
\text { Management Journal }\end{array}$ & 2005 & 1339 \\
\hline $\begin{array}{l}\text { Evolving sustainably: A longitudinal study } \\
\text { of corporate sustainable development }\end{array}$ & Bansal, P [60] & $\begin{array}{l}\text { Strategic Management } \\
\text { Journal }\end{array}$ & 2005 & 926 \\
\hline $\begin{array}{l}\text { Corporate citizenship: Toward an extended } \\
\text { theoretical conceptualization }\end{array}$ & Matten, D; Crane, A [61] & $\begin{array}{c}\text { Academy of } \\
\text { Management Review }\end{array}$ & 2005 & 746 \\
\hline $\begin{array}{l}\text { Corporate governance and competitive } \\
\text { advantage in family-controlled firms }\end{array}$ & Carney, M [62] & $\begin{array}{l}\text { Entrepreneurship } \\
\text { Theory and Practice }\end{array}$ & 2005 & 624 \\
\hline $\begin{array}{l}\text { The micro-determinants of meso-level } \\
\text { learning and innovation: evidence from a } \\
\text { Chilean wine cluster }\end{array}$ & Giuliani, E; Bell, M [63] & Research Policy & 2005 & 567 \\
\hline $\begin{array}{l}\text { Interorganizational collaboration and } \\
\text { innovation: Toward a portfolio approach }\end{array}$ & $\begin{array}{l}\text { Faems, D; Van Looy, B; } \\
\text { Debackere, K [64] }\end{array}$ & $\begin{array}{l}\text { Journal of Product } \\
\text { Innovation } \\
\text { Management }\end{array}$ & 2005 & 566 \\
\hline $\begin{array}{l}\text { Structural vs. relational embeddedness: } \\
\text { Social capital and managerial performance }\end{array}$ & Moran, P [65] & $\begin{array}{l}\text { Strategic Management } \\
\text { Journal }\end{array}$ & 2005 & 554 \\
\hline $\begin{array}{l}\text { R\&D alliances and firm performance: The } \\
\text { impact of technological diversity and alliance } \\
\text { organization on innovation }\end{array}$ & Sampson, Rachelle C. [66] & $\begin{array}{c}\text { Academy of } \\
\text { Management Journal }\end{array}$ & 2007 & 532 \\
\hline
\end{tabular}

The analysis concerning the networks of co-cited journals more often cited in the scope of the current SLR, reveals that the most co-cited journal is the "Strategic Management Journal", followed by the "Research Policy", the "Academy of Management Journal" and the "Academy Management Review" (see Figure 5). We can observe that these four more oftentimes cited journals, all have at least one publication in the top 10 most cited publications of this SLR. 


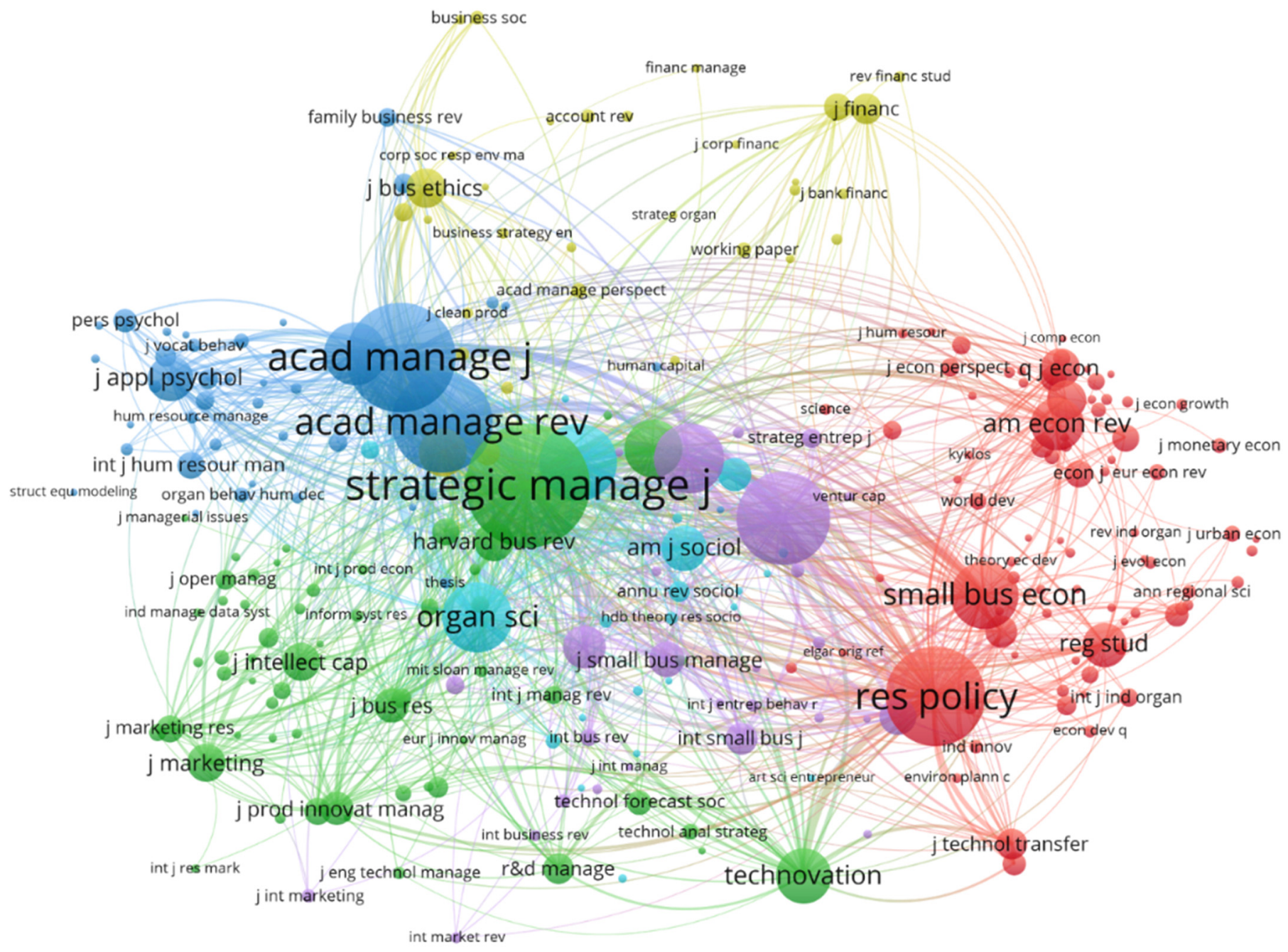

Figure 5. Visualization of the co-cited journals (Source: Own elaboration using the VOSviewer software).

\subsection{Citation Analysis}

Since the majority of the studies in this SLR was developed in co-authorship, meaning two or more authors participated in the publication, in order to attest which authors participated more in the 1614 publications, the VOSviewer software was used in order to perform the bibliometric analysis [55]. Figure 6 represents the authors or co-authors that participated more in the 1614 publications. Only authors or co-authors with two or more publications were displayed in Figure 6 due to the immense number of different authors and co-authors (3520) in the 1614 publications analyzed in this study. The nodes represent the authors and the lines indicate the relationships between authors. Notably, David Audretsch and Mike Wright are the two most prominent authors in this line of work, with 29 publications each. David Audretsch's research mainly focuses on the relationship between entrepreneurship, government policy, innovation and economic development, while Mike Wright also focuses on entrepreneurship but also on strategic management, academic entrepreneurship and venture capital. Authors such as Dean Shepherd and Joern Block, also stand out with seven and six publications, respectively (see Figure 6). Dean Shepherd dedicates his research to entrepreneurship, social entrepreneurship, decision making and organizational performance. In turn, Joern Block's research is focused on entrepreneurship, innovation, and family business, at the individual, firm, and country level. 


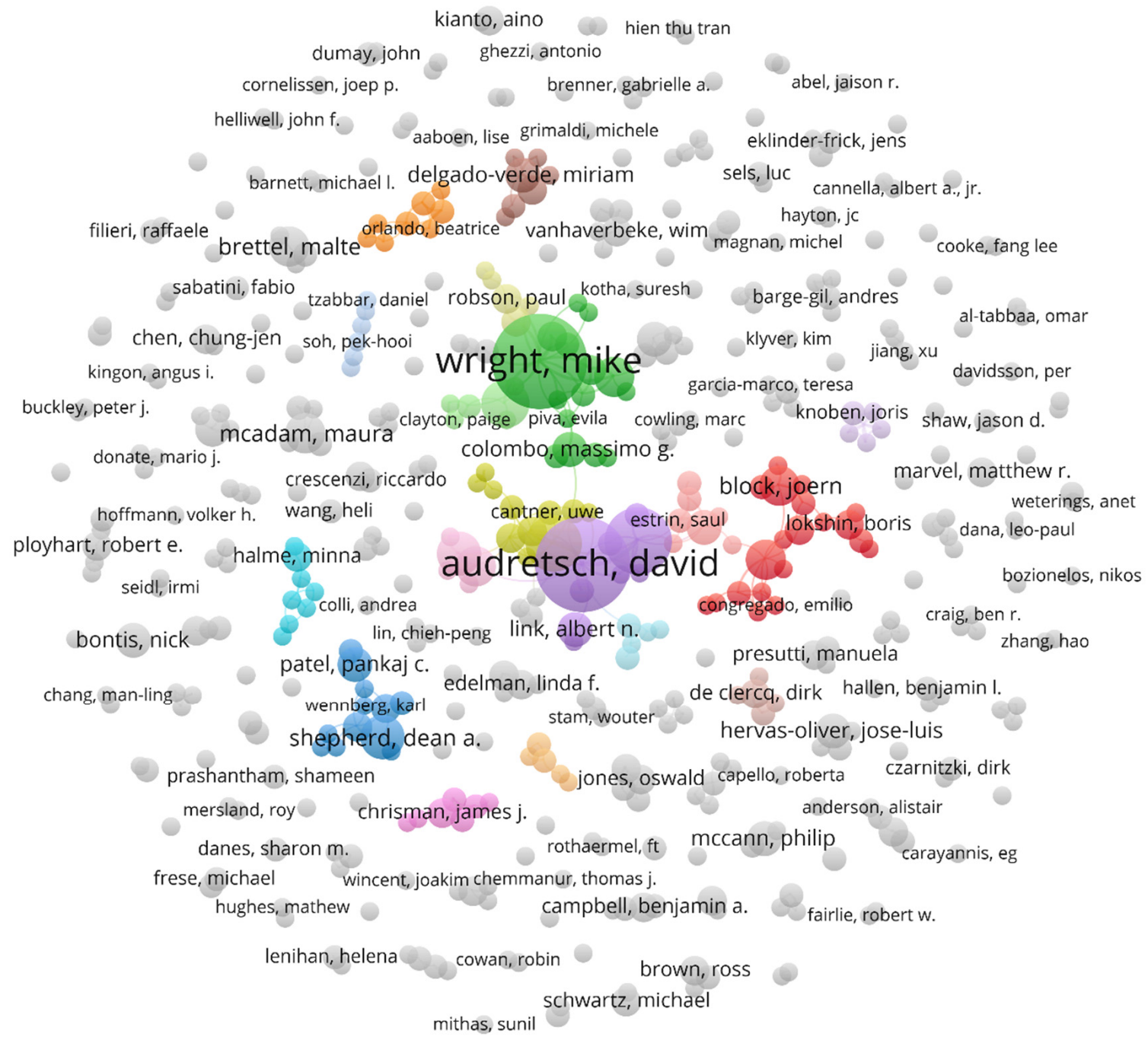

Figure 6. Authors and co-authors participating most often in the 1614 publications (Source: Own elaboration using the VOSviewer software).

\subsection{Co-Citation Analysis}

There were 33.674 co-cited authors identified with the VOSViewer software. In order to identify the most co-cited authors, signifying the number of times the authors are cited together, the sample was reduced to authors with a minimum of 25 citations (as proposed by [32], thus reducing the sample to 777 authors. The size of the node is proportional to the number of citations and the proximity between nodes indicates a greater relation between authors. As can be seen in Figure 7, the most prominent authors can be identified by identifying the larger nodes; the blue node, led by David Audretsch (462 citations), the green node, headed by Scott Shane (436 citations), the yellow node, guided by Shaker Zahra (396 citations), and finally the red node, led by Wesley Cohen (390 citations). 


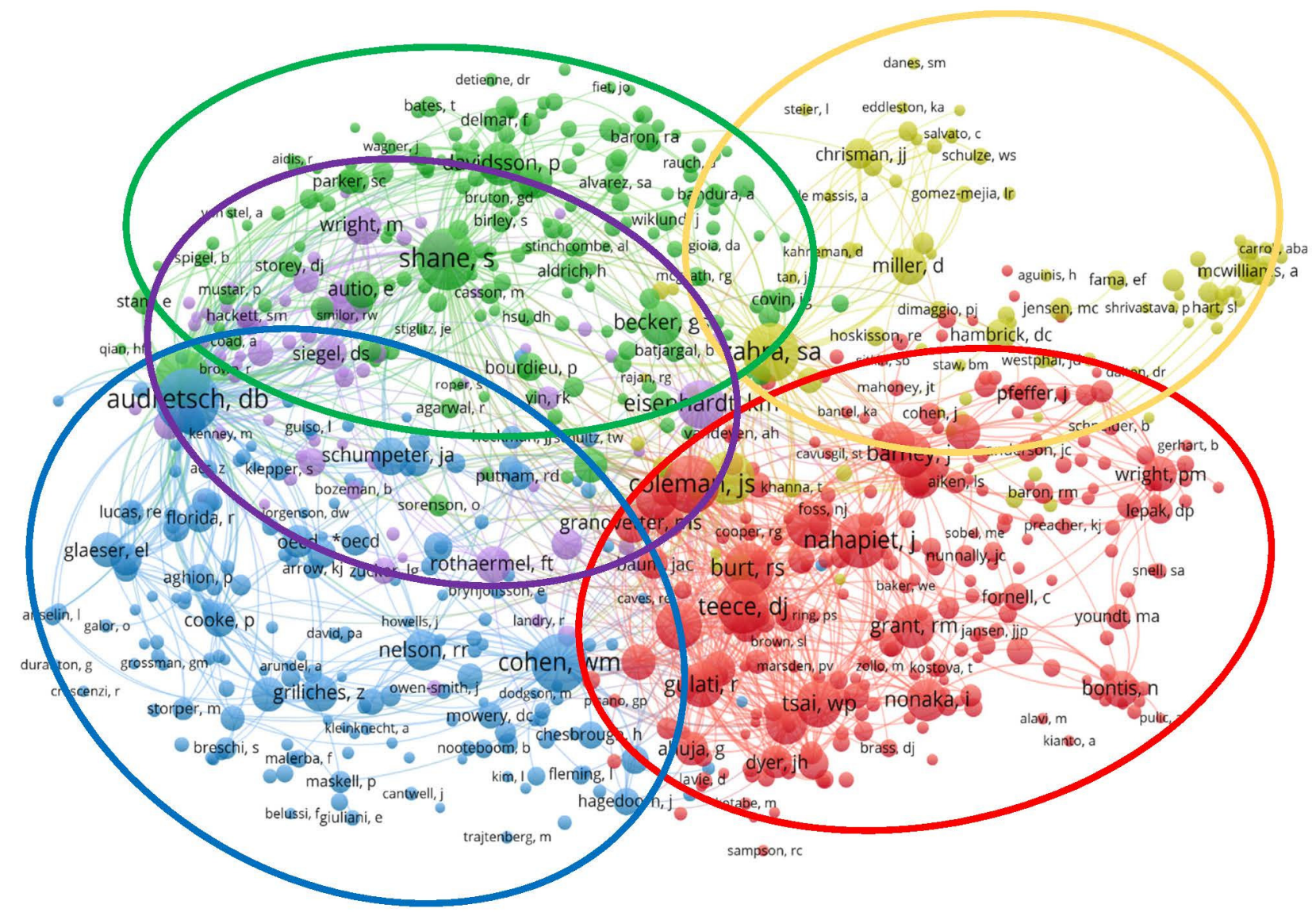

Figure 7. Co-citation authors (Source: Own elaboration using the VOSviewer software).

\subsection{Word Co-Occurrence Cluster Analysis}

Concerning the analysis of the word co-occurrence (see Figure 8) in the abstract, title of the publications, and keywords, it is possible to identify that the most prominent subjects are: performance (450 occurrences), innovation (415), knowledge (263), networks (234), social capital (230), entrepreneurship (218), human capital (213), management (171), growth (203), and research and development (171).

This analysis is often used to discover links between subjects, allowing for the definition of a field of research [67]. This analysis was made using the text mining tool of the VOSviewer software. Thus, the title, abstract and keywords of the 1614 publications were analyzed using the binary counting method, as only the presence or absence of a term in a document is taken into account. In the current analysis, 116 terms were found, with a minimum occurrence of 25 times. After a careful visualization of all of the terms found, some were removed since they were deemed irrelevant (article, author, year, study) [68,69]. Figure 8 provides an overview of the relationships between words, as it is determined by the amount of articles in which they appear jointly [55]. The relationship between terms reflects the number of publications in which they occur together $[55,70]$. The observation of these networks reveals topics with possible interest for further exploration and development, in terms of research agenda and policy action [32]. 


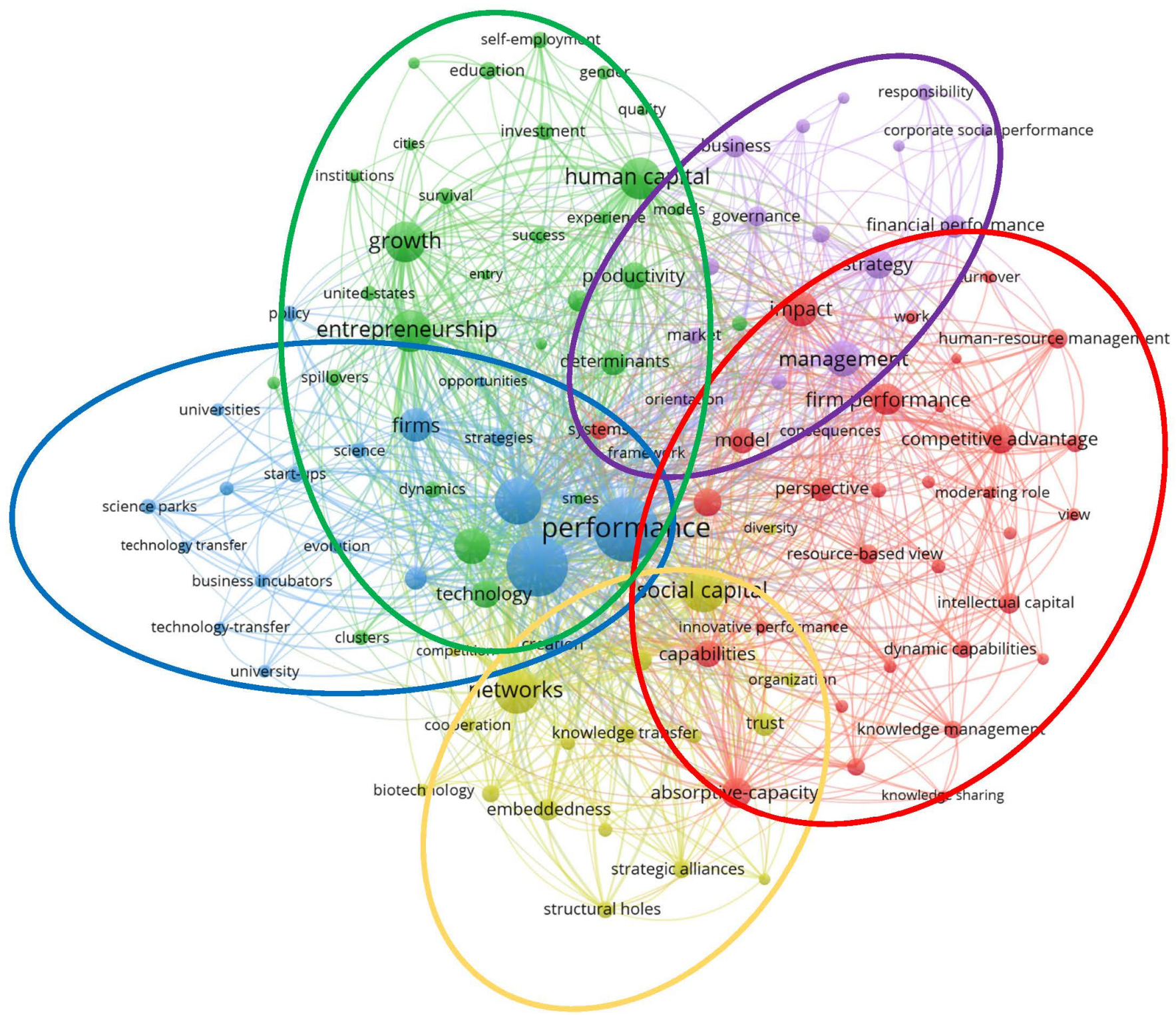

Figure 8. Word co-occurrence (Source: Own elaboration using the VOSviewer software).

Again, taking as reference the results presented in Figure 8, the existence of five clusters is detected, based on the relationships between different terms and their associations in groups. The first cluster (in green) is composed of 32 terms, between them the most prevalent of which are: human capital, growth, entrepreneurship, productivity, technology, determinants, dynamic, and education. This cluster was named: human capital as a determinant of productivity and growth in technology-based ventures.

The second cluster (purple) is composed of 16 terms, among them the most prevalent: management, strategy, market, financial performance, corporate social performance, governance, business, corporate social responsibility, and economic performance. This cluster was named: impact of corporate social performance and corporate social responsibility on business management strategies.

The third cluster (red) is constituted by 32 terms, among them the most prevalent: firm performance, impact, absorptive-capacity, competitive advantage, and capabilities. This cluster was designated as: absorptive-capacity and its role in the competitive advantage and performance of the firm.

The fourth cluster (yellow) is composed of 18 terms, between them the most relevant are: networks, social capital, knowledge transfer, cooperation, strategic alliances, and em- 
beddedness. This cluster was named: the role of business networks, business cooperation and strategic alliances towards knowledge transfer.

The fifth cluster (blue) is composed of 20 terms, being the most prevalent the following: performance, innovation, knowledge, firms, strategies, science parks, technology transfer, business incubators, universities, and policy. This cluster was named: the role of science parks and business incubators in the technology transfer of the knowledge and innovation created in universities. Next an analysis of each cluster is presented.

Cluster 1: Human capital as a determinant of productivity and growth in technologybased ventures.

Human capital is of extreme importance to the performance, success, and growth of technology-based ventures. As a matter of fact, it was found that the founding team's human capital effects the company in a stronger way in the growth stage [71]. In fact, the human capital of the founders, specifically their education and work experience, was found to affect firm's growth [72]. As such, human resources are essential, and the optimization of their skills and knowledge can improve the firm's probability of success [73]. Human resources are a very important factor for the innovativeness of an organization [74].

It was also found that human capital diversity of the top management teams moderates the relationship between venturing activities and innovation and financial performance in these ventures [75]. The three intellectual capital components (human, socia, and organizational) are enhancers of open innovation [76].

Interestingly, it was stated that the formation of entrepreneurship-specific human capital can be influenced by education targeted specifically to entrepreneurship [77].

Human capital relates strongly to performance, and increasing human capital will inevitably increase performance [78]. That being said, to improve performance, firms should attract, invest, and develop human capital; and they should also retain their already very experienced employees.

It has also been documented that places with higher levels of human capital attract more skilled people [79]. In turn, skilled human capital enhances the growth in economies closer to the technological frontier [80].

Cluster 2: Impact of corporate social performance and corporate social responsibility on business management strategies.

This cluster is closely connected with social capital. Corporate social performance is a difficult construct to define, but can be defined as the principles and outcomes of relationships with people, organizations, communities, and societies in terms of the actions of businesses towards the different stakeholders [81]. While corporate social responsibility refers to corporate actions that aim to serve people, communities, and the environment [82]

Social capital is important for performance, mainly its structural and relational components. Structural capital is important for sales performance while relational capital is essential for innovation performance [65]. Moreover, to effectively pursue open innovation practices, the firms should develop relational capital to be able to benefit from cross-organizational synergies [76].

Entrepreneurs can enhance the performance of their businesses by building social ties to other firms in their industry [83], and having a diverse network of relationships can positively impact performance [84]. Social capital can be a predictor of organizational performance, particularly social capital developed from social networking relationships [85]. As such, corporate social performance can aid the firm's financial performance [86]. It was also found that effective corporate social responsibility strategies entail better environmental and social performance [87], moreover corporate social responsibility is positively correlated with the financial performance of the firm [82].

Cluster 3: Absorptive-capacity and its role in the competitive advantage and performance of the firm.

This cluster connects with Organizational Capital. Absorptive capacity emphasizes the processes of building up technological knowledge in the firm, and outside of it; and suggests that knowledge contributes to the firms' competitive advantage [88]. Absorptive capacity is 
cumulative, and built over time, increasing knowledge and the potential to absorb further knowledge, moreover, absorptive capacity can be activated in instances that facilitate collaborative interchanges of knowledge acquisition, assimilation and transformation [89]. On the other hand, in high technology environments, rapid changes occur, so the value of a firm's existing knowledge is diminished [75]. These firms' absorptive capacity is influenced by the top management, as they are an important source of inherited knowledge [75].

The entrepreneur's absorptive capacity is critical to new firm formation, as knowledge spillover entrepreneurship depends on new knowledge but also on entrepreneurial absorptive capacity that allows entrepreneurs to understand new knowledge, recognize its value, and commercialize it by creating a new venture [90]. Intellectual capital does indeed influence absorptive capacity, and in its turn absorptive capacity influences product innovation [91]. Moreover, it was found that management experience positively stimulates absorptive capacity in dynamic environments, on the other hand, it hinders absorptive capacity in stable environments [92]. In order to have better performance and generate innovation, firms must get involved in coopetition arrangements [93].

Cluster 4: The role of business networks, business cooperation and strategic alliances towards knowledge transfer.

This cluster is closely connected with social capital. The establishment of business networks can attenuate environmental influences on business development, positively influencing new venture survival [94,95].

Strategic alliances have been of importance for quite some time, and they arose due to the need to spread the costs and risks of innovation [96], and they propagated as interorganizational relationships. These cooperative arrangements represent a new organizational formation that wants to achieve its objectives through cooperation, rather than through competition [97]. The probability for university-business cooperation increases if businesses use open knowledge sourcing strategies [98].

University cooperation is more likely if businesses are producing new innovations [98]. University-industry cooperation is fundamental for the knowledge transfer performance [99]. Most university inventions need further development, so this results in nearly $75 \%$ of university inventions not being licensed, which means that the innovation created is not being transferred to the industry [100]. Knowledge transfer entails the dissemination of knowledge and the provision of inputs for problem solving [101]. Knowledge transfer is influenced by cooperation, relationship with institutions, workforce mobility and geographical proximity [102].

Cluster 5: The impact of business incubators in the technology transfer of the knowledge and innovation created in universities.

This cluster is linked with organizational capital. The literature on business incubators, either created by public institutions or private firms, and their performance has grown immensely in the last 50 years.

The more academic research is produced, the more research and technology can be transferred to industry. Here one can find technology transfer dynamics to boost the transfer of the knowledge created in academia and the industry. Technology transfer aims to disseminate knowledge and technologies to the industry through a variety of mechanisms: collaborative research, contract research, consulting, technology licensing, training and staff exchanges [103]. Thus being that university-industry cooperation is pivotal to knowledge transfer performance [99]. Notwithstanding, most university inventions are embryonic, meaning that they need further development. This results in nearly 75\% of university inventions not being licensed, which means that the innovation created is not being transferred to the industry [100]. Moreover, the presence of support structures, such as universities, research centers or laboratories, increases the likelihood of new venture creation [104]. 


\subsection{Research Questions: Contrasting Literature and Findings}

Recovering the MRQ: "How incubation and acceleration ecosystems foster the adoption of open innovation practices influencing the performance of technology-based ventures along their life cycle?", we analysed the literature pertaining to BA and BI, their actions as facilitators of open innocation practices, and their influence over the performance of startups.

The process of incubation can provide a number of contributions to the development of high-technology firms [105], providing resources, capabilities, knowledge, and social capital, however, the influence of these intermediary benefits on startup performance is ambiguous [106]. Nevertheless, the image effect of a BI (e.g., media presence, wordof-mouth), seems to be an enormous advantage [19]. This can imply that BIs should update their service portfolio while simultaneously imposing stricter selection criteria and introducing exit policies [107].

Incubation and acceleration ecosystems serve as facilitators for open innovation practices as these practices allow the companies to foster alliances [34].

It is also noticeable that younger firms value the credibility that they get through the acceptance into an incubator [108]. As the firms matured, belonging to a BI could be associated with newness, vulnerability and inexperience [108], and could be perceived as less disadvantageous. Younger firms are more available to be open organizations, as they are necessarily involved in the innovation process [39].

The success of a BI depends on the performance of ventures in its portfolio [109] and thus a BI benefits from limiting the tenant failure rate [3]. BA companies learn to cut losses earlier and shut down accordingly. Even though BA companies raise less money on average, the funding ratio is lower, meaning that more money is invested in companies that eventually get acquired than in companies that eventually close [28].

BI do not increase the likelihood of firm survival, innovativeness, and growth [110]. Conversely, some studies found that BI are, on their own, insufficient to exert an influence on business survival [111-114], and therefore raising some doubts regarding the impacts of incubation on long-term firm survival.

In contrast with the aforementioned, university incubators give credibility to a firm, as they can offer a professional image and valuable social networks [21]. The support provided by a BI or a science park is proven to be of key importance, not only since it provides mentoring and facilities but it is also a guarantee of reliability in front of potential clients, suppliers, employees and in front of banks that are more inclined to give loans to firms positively evaluated by a university incubator $[21,115]$.

Previous research reveals that the association of BI with local universities provide incubated ventures with knowledge, skills, and R\&D facilities [116], being the mentorship provided, and are of extreme importance in the cases where the startups lack business competences [115]. Moreover, incubating in a university incubator enhances the firms sustainability, offering a big opportunity for future growth [21].

BA are undoubtedly becoming increasingly visible across a large number of entrepreneurial ecosystems. BA play a central role in shaping entrepreneurial activity and act as powerful enablers of transnational entrepreneurship [117].

Concerning the SRQ1: Does the specialization of incubation and acceleration ecosystems facilitates the adoption of open innovation practices influencing the performance of technology-based ventures along their life cycle?; we analyzed the effect of the specialization of the ecosystem on the performance of startups.

A specialized BI is a BI with focus on a specific sector or a limited number of sectors [3]. An increasing number of BI focus their activities on one specific sector, however the benefits arising from this specialization have not been explored in great detail [19]. For example, a previous work of the authors details a Portuguese incubator focused in the bio health sector, being this specialization highly praised in instances as the provided facilities and the specialized staff [37]. 
Importantly, it was found that the sharing of technical resources is only profitable in the case of a specialized incubator [14]. It is impossible to provide sector-specific knowledge and business support for a plethora of heterogeneous sectors with the same quality [110]. Thus, if the incubator is specialized on a defined sector, it increases the expertise of the management team [3] and also the incubator's value to the incubated startups [19]. The major determinant factors to the decision to locate at a BI is access to research facilities and laboratories [118], business support, grants and potential financial investors. [119].

There is no positive or negative effects of being incubated in a specialized BI regarding the promotion of networking between the incubates and academic institutions, they found that the specialization of the incubator brings no added value compared to a generic incubator [120].

However, the specialization of the incubator can bring about some disadvantages, namely the increased vulnerability of the incubator, if the sector of specialization suffers, the incubator will consequently suffer [3].

It is noteworthy to mention the lack of literature in what pertains to specialized BI, and even more in what pertains to open innovation practices in specialized BI.

In what relates to the SRQ2: What are the types of capital related with the adoption of open innovation practices influencing the performance of technology-based ventures along their life cycle?; we analysed the types of capital that influence the performance of startups.

On one hand, human and social capital, structures and systems and networks influence learning and growth [121]; on the other human capital is said to have a negative influence on innovative capability, this implies that individual expertise is not encouraging of innovation [59]. Conversely, social capital has an important positive influence on knowledge transfer [58].

Relating to organizational capital, it was found to positively influence innovative capability [59] whereas social capital is described to be the foundation of innovative capabilities.

Concerning intellectual capital, the dimensions considered as critical for the success of the entrepreneurial ecosystem are the structural capital and the relational capital (although human capital is perceived as a basic prerequisite for fostering the entrepreneurial ecosystem's performance) [37].

It has been pointed out that the skills of the incubator's staff positively affect the incubator activity, and thus the formation of new technology-based ventures [104]. It is also worth mentioning that the relationship between the incubator manager/director and the incubated ventures has a significant role in performance [105].

Regarding the SRQ3: What are the research gaps in the literature concerning incubation and acceleration ecosystems, facilitators of open innovation practices, and technology-based ventures performance?; We identified some gaps in the literature that suggest the need for further research.

The benefits of BI specialization have not been fully studied and identified [19]. The existing research revolving around BA is fragmented and sparse, as a literature gap remains regarding the understanding of how BA impact and interact with their local ecosystem [24]. Also, there is a need for further research regarding the BI and BA's regional impact.

There is also a literature gap relating to the process of incubation itself [122], for instance the finer aspects of what type of knowledge to accumulate/incentivize by the management teams, or regarding what pertains to the efficiency of incubation initiatives that best benefit the incubated ventures [123].

\subsection{Taxonomy Proposal}

Taxonomy is best known for being used as a classification system for the plant and animal kingdom. Nonetheless, taxonomy can be defined as a means of organizing knowledge, providing a structure of concepts, using terms that aid in knowledge sharing [124]. Based on the research questions of this SLR, mainly related to the specialization and the various different types of capital, a taxonomy for BI and BA was proposed, in order to allow for the advancement of this field of research. 
Based on the empirical findings of this SLR, the main contribution resides in the presentation of a new taxonomy (see Figure 9) for the classification of BI and BA, according to three pillars: human capital, social capital, and organizational capital. This taxonomy will allow for the unequivocal classification of BI and BA, targeted to facilitating the adoption of open innovation practices.

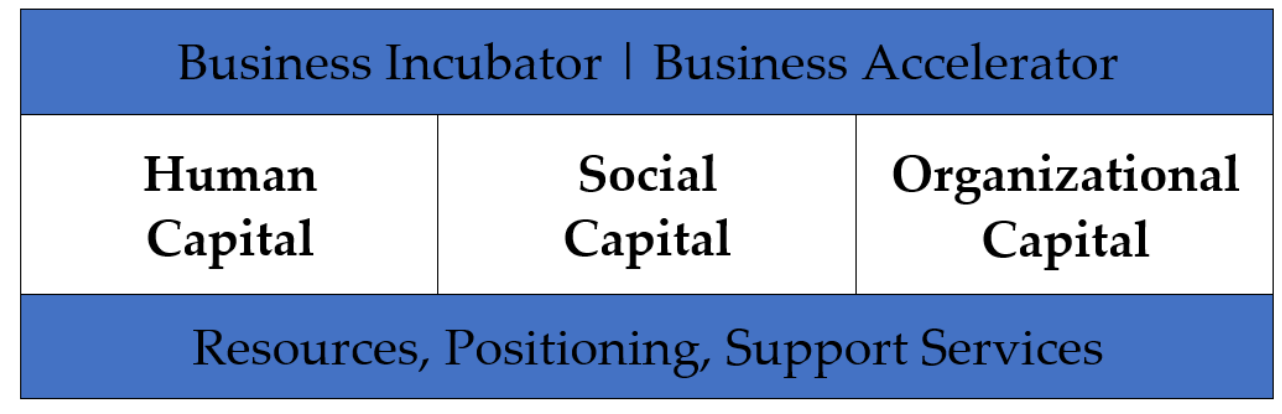

Figure 9. Taxonomy of the capitals that support the facilitators of open innovation of BI and BA (Source: Own elaboration).

Bearing in mind the first pillar, human capital, it should be fostered, as it encompasses the staff, their expertise.

The second pillar, social capital, is related with the creation of networks, but also relates with the corporate social performance.

The third pillar, organizational capital, encompasses the physical structure of the BI, meaning the building and its components, for instance, structures such as laboratories, re-search facilities, auditoriums, conference rooms, etc.

\section{Concluding Remarks}

\subsection{Debate, Limitations and Implications}

This comprehensive systematic literature review (SLR) encompassed 1614 publications, obtained through a rigorous data collection process, which allowed for the presentation of a new taxonomy of the capitals of BI and BA, here positioned as fundamental levers for facilitating the adoption of open innovation practices.

Considering the main research question posed in this SLR, it is noteworthy that BI and BA help in the development of new high-technology ventures, by being facilitators for open innovation practices, by providing space, knowledge, networking, training, and mentorship, and by being highly valued in terms of the credibility that being associated to a University BI or BA gives to incubated venture.

Considering the influence of the specialization of BI or BA in the performance of startups, the findings reveal to us that the specialization of BI or BA is profitable when sharing resources, and extremely useful in the instances where the staff is also specialized. Nonetheless, it is worth noting that for being specialized, these BI/BA are vulnerable if the sector of specialization suffers. Taking into account the types of capital that influence the performance of startups, the authors found that human, social, and organizational capital have influence on the performance of startups, focusing largely on intellectual capital.

As one limitation, this SLR is obviously limited by the literature, as the collection of publications was performed exclusively through ISI Web of Science (WoS). Although this is the most comprehensive database available for this kind of study, it is by no means exhaustive.

\subsection{Future Research}

Several research gaps were identified in the literature in the scope of this SLR, mainly the lack of information on specialized BI and BA. There is also a gap in literature in terms of what concerns the knowledge the management team must possess. The impact of BI and $\mathrm{BA}$ in their region also warrants further research endeavors. 
In that scope, the gaps encountered in this work should be developed into a future research agenda, focusing on the influence of BI and BA on the growth, survival, and innovative performance of firms, while also studying the influence of intellectual capital in the performance of startups. This research agenda could be fruitful and really contribute to the state-of-the-art, if developed taking into account a specialized BI/BA ecosystem.

The number of BI and BA is still growing, and a topic for further research is whether these structures impact the diversification of regional economies (and, if so, to what extent). Moreover, further research is needed to paint a clearer picture of the particularities of the structures of incubation and acceleration and how they can contribute to the success of the incubated ventures. The literature on the subject of BI specialization is extremely narrow, so there is a prevailing need for further research on this subject. Lastly, using a knowledge spillover approach, a possible extension of the current study is to assess whether these structures impact open innovation practices at the regional level.

Author Contributions: Conceptualization, J.L.; validation, D.P.; data curation, Â.G.; writingoriginal draft preparation, Â.G.; simulation, Â.G.; writing-review and editing, J.L. and D.P. All authors have read and agreed to the published version of the manuscript.

Funding: The Portuguese Foundation for Science and Technology (Grants and NECE- UIDB/4630/2020) provided financial support for this study.

Institutional Review Board Statement: Not applicable.

Informed Consent Statement: Not applicable.

Data Availability Statement: Not applicable.

Acknowledgments: The authors acknowledge the highly valuable comments and suggestions provided during the revision process, which contributed to the improvement in the clarity, focus, contribution and scientific soundness of the current study.

Conflicts of Interest: The authors declare no conflict of interest.

\section{References}

1. Szabó, A. Business Incubation as Element of Business Service Institution and SME Development Infrastructure for Creation of New Enterprises in CITs; ERENET: Budapest, Hungary, 2006.

2. Abetti, P.A. Government-Supported Incubators in the Helsinki Region, Finland: Infrastructure, results, and best practices. J. Technol. Transf. 2004, 19-40. [CrossRef]

3. Aerts, K.; Matthyssens, P.; Vandenbempt, K. Critical role and screening practices of European business incubators. Technovation 2007, 27, 254-267. [CrossRef]

4. Hillemane, B.; Satyanarayana, K.; Chandrashekar, D. Technology business incubation for start-up generation: A literature review toward a conceptual framework. Int. J. Entrep. Behav. Res. 2019, 25, 1471-1493. [CrossRef]

5. Hausberg, J.P.; Korreck, S. Business incubators and accelerators: A co-citation analysis-based, systematic literature review. J. Technol. Transf. 2020, 45, 151-176. [CrossRef]

6. Sofouli, E.; Vonortas, N.S. S\&T Parks and business incubators in middle-sized countries: The case of Greece. J. Technol. Transf. 2007, 32, 525-544. [CrossRef]

7. Alsos, G.A.; Hytti, U.; Ljunggren, E. Stakeholder theory approach to technology incubators. Int. J. Entrep. Behav. Res. 2011, 17, 607-625. [CrossRef]

8. Regmi, K.; Ahmed, S.A.; Quinn, M. Data Driven Analysis of Startup Accelerators. Univers. J. Ind. Bus. Manag. 2015, 3, 54-57. [CrossRef]

9. Cohen, S. What Do Accelerators Do ? Insights from Incubators and Angels. Innov. Technol. Gov. Glob. 2013, 8, 19-25.

10. Battistella, C.; De Toni, A.F.; Pessot, E. Framing open innovation in start-ups' incubators: A complexity theory perspective. J. Open Innov. Technol. Mark. Complex. 2018, 4, 33. [CrossRef]

11. Le Trinh, T. Factors affecting startup performance of small and medium-sized enterprises in Danang city. Entrep. Bus. Econ. Rev. 2019, 7, 187-203. [CrossRef]

12. Audretsch, D.; Keilbach, M. Entrepreneurship capital and economic performance. Reg. Stud. 2004, 38, 949-959. [CrossRef]

13. Pustovrh, A.; Rangus, K.; Drnovšek, M. The role of open innovation in developing an entrepreneurial support ecosystem. Technol. Forecast. Soc. Chang. 2020, 152, 119892. [CrossRef]

14. Chan, K.F.; Lau, T. Assessing technology incubator programs in the science park: The good, the bad and the ugly. Technovation 2005, 25, 1215-1228. [CrossRef] 
15. Clarysse, B.; Wright, M.; Lockett, A.; Velde, E.V.D.; Vohora, A. Spinning out new ventures: A typology of incubation strategies from European research institutions. J. Bus. Ventur. 2005, 20, 183-216. [CrossRef]

16. Hackett, S.M.; Dilts, D. A Systematic Review of Business Incubation Research. J. Technol. Transf. 2004, 29, 55-82. [CrossRef]

17. Hackett, S.M. A Real Options-Driven Theory of Business Incubation A Real Options-Driven Theory of Business Incubation. J. Technol. Transf. 2004, 29, 41-54. [CrossRef]

18. Hsu, P.; Shyu, J.Z.; Yu, H.; Yuo, C.; Lo, T. Exploring the interaction between incubators and industrial clusters: The case of the ITRI Incubator in Taiwan. RED Manag. 2003, 33, 79-90.

19. Schwartz, M.; Hornych, C. Specialization as strategy for business incubators: An assessment of the Central German Multimedia Center. Technovation 2008, 28, 436-449. [CrossRef]

20. Tomy, S.; Pardede, E. An entrepreneurial intention model focussing on higher education. Int. J. Entrep. Behav. Res. 2020, 26, 1423-1447. [CrossRef]

21. McAdam, M.; Marlow, S. A preliminary investigation into networking activities within the university incubator. Int. J. Entrep. Behav. Res. 2008, 14, 219-241. [CrossRef]

22. Pauwels, C.; Clarysse, B.; Wright, M.; Van Hove, J. Understanding a new generation incubation model: The accelerator. Technovation 2016, 50-51, 13-24. [CrossRef]

23. Bliemel, M.; De Klerk, S. The Role and Performance of Accelerators in the Australian Startup Ecosystem; Department of Industry, Innovation \& Science: Canberra, Australia, 2016.

24. Cohen, S.; Fehder, D.C.; Hochberg, Y.V.; Murray, F. The design of startup accelerators. Res. Policy 2019, 48, 1781-1797. [CrossRef]

25. Hochberg, Y.V. Accelerating entrepreneurs and ecosystems: The seed accelerator model. Innov. Policy Econ. 2016, 16, 25-51. [CrossRef]

26. Malek, K.; Maine, E.; McCarthy, I.P. A typology of clean technology commercialization accelerators. J. Eng. Technol. Manag. JET-M. 2014, 32, 26-39. [CrossRef]

27. Price, R. The role of service providers in establishing networked regional business accelerators in Utah. Int. J. Technol. Manag. 2004, 27, 465-474. [CrossRef]

28. $\mathrm{Yu}, \mathrm{S}$. How Do Accelerators Impact the Performance of High-Technology Ventures? SSRN Electron. J. 2018. [CrossRef]

29. Bahrami, H.; Evans, S. Flexible Re-Cycling and High-Technology Entrepreneurship. Calif. Manag. Rev. 1995, 37, 62-89. [CrossRef]

30. Jacobides, M.G.; Cennamo, C.; Gawer, A. Towards a theory of ecosystems. Strateg. Manag. J. 2018, 39, 2255-2276. [CrossRef]

31. Audretsch, D.B.; Cunningham, J.A.; Kuratko, D.F.; Lehmann, E.E.; Menter, M. Entrepreneurial ecosystems: Economic, technological, and societal impacts. J. Technol. Transf. 2018, 44, 313-325. [CrossRef]

32. De Brito, S.; Leitão, J. Mapping and defining entrepreneurial ecosystems: A systematic literature review. Knowl. Manag. Res. Pract. 2021, 19, 21-42. [CrossRef]

33. Chesbrough, H.W. The era of open innovation. Managing innovation and change. MIT Sloan Manag. Rev. 2003, $44,35-41$.

34. Sabando-Vera, D.; Yonfa-Medranda, M.; Montalván-Burbano, N.; Albors-Garrigos, J.; Parrales-Guerrero, K. Worldwide Research on Open Innovation in SMEs. J. Open Innov. Technol. Mark. Complex. 2022, 8, 20. [CrossRef]

35. Bergek, A.B.; Norrman, C. Incubator best practice: A framework. Technovation 2008, 28, 20-28. [CrossRef]

36. Calza, F.; Dezi, L.; Schiavone, F.; Simoni, M. The intellectual capital of business incubators. J. Intellect. Cap. 2014, 15, 597-610. [CrossRef]

37. Gonçalves, Â.; Pereira, D.; Leitão, J.; Fuentes, M.d.M. Understanding Bio Health Technologies Entrepreneurial Ecosystems: An Intellectual Capital Approach. In The Handbook of Open Smart Cities: Planning and Managing Open Innovative Ecosystems; Emerald Publishing Limited: Bingley, UK, 2020; pp. 13-40. ISBN 9781789734096.

38. West, J.; Gallagher, S. Challenges of open innovation: The paradox of firm investment in open-source software. RED Manag. 2016, 36, 319-331.

39. Spender, J.C.; Corvello, V.; Grimaldi, M.; Rippa, P. Startups and open innovation: A review of the literature. Eur. J. Innov. Manag. 2017, 20, 4-30. [CrossRef]

40. Fernandes, A.; Ferreira, J.J. Entrepreneurial ecosystems and networks: A literature review and research agenda. Rev. Manag. Sci. 2021, 16, 189-247. [CrossRef]

41. Kraus, S.; Dasí-rodríguez, S. The art of crafting a systematic literature review in entrepreneurship research. Int. Entrep. Manag. J. 2020, 16, 1023-1042. [CrossRef]

42. Mazzoni, L.; Lazzeretti, L.; Innocenti, N. Entrepreneurship, complexity and the emergent order in the techno-economic scenario of the twenty-first century. Evidence from a field study in Tuscany. Ind. Innov. 2021, 28, 570-593. [CrossRef]

43. Pita, M.; Costa, J.; Moreira, A.C. Entrepreneurial Ecosystems and Entrepreneurial Initiative: Building a Multi-Country Taxonomy. Sustainability 2021, 13, 4065. [CrossRef]

44. Tranfield, D.; Denyer, D.; Smart, P. Towards a Methodology for Developing Evidence-Informed Management Knowledge by Means of Systematic Review. Br. J. Manag. 2003, 14, 207-222. [CrossRef]

45. Rowley, J.; Slack, F. Conducting a literature review. Manag. Res. News 2004, 27, 31-39. [CrossRef]

46. Mulrow, C.D. Systematic reviews: Rationale for systematic reviews. Br. Med. J. 1994, 309, 597-599. [CrossRef] [PubMed]

47. Oakley, A. Social science and evidence-based everything: The case of education. Educ. Rev. 2002, 54, 277-286. [CrossRef]

48. Falagas, M.E.; Pitsouni, E.I.; Malietzis, G.A.; Pappas, G. Comparison of PubMed, Scopus, Web of Science, and Google Scholar: Strengths and weaknesses. FASEB J. 2008, 22, 338-342. [CrossRef] 
49. Li, K.; Rollins, J.; Yan, E. Web of Science use in published research and review papers 1997-2017: A selective, dynamic, crossdomain, content-based analysis. Scientometrics 2018, 115, 1-20. [CrossRef]

50. Ordanini, A.; Rubera, G.; DeFillippi, R. The many moods of inter-organizational imitation: A critical review. Int. J. Manag. Rev. 2008, 10, 375-398. [CrossRef]

51. Podsakoff, P.M.; Mackenzie, S.B.; Bachrach, D.G.; Podsakoff, N.P. The influence of management journals in the 1980s and 1990s. Strateg. Manag. J. 2005, 26, 473-488. [CrossRef]

52. Ramos-Rodrígue, A.R.; Ruíz-Navarro, J. Changes in the intellectual structure of strategic management research: A bibliometric study of the Strategic Management Journal, 1980-2000. Strateg. Manag. J. 2004, 25, 981-1004. [CrossRef]

53. Keupp, M.M.; Palmié, M.; Gassmann, O. The Strategic Management of Innovation: A Systematic Review and Paths for Future Research. Int. J. Manag. Rev. 2012, 14, 367-390. [CrossRef]

54. Garfield, E. Journal impact factor: A brief review. Cmaj 1999, 161, 979-980. [PubMed]

55. van Eck, N.J.; Waltman, L. Software survey: VOSviewer, a computer program for bibliometric mapping. Scientometrics 2010, 84, 523-538. [CrossRef] [PubMed]

56. Laursen, K.; Salter, A. Open for innovation: The role of openness in explaining innovation performance among U.K. manufacturing firms. Strateg. Manag. J. 2006, 27, 131-150. [CrossRef]

57. Culnan, M.; O'Reilly, C.; Chatman, J. Intellectual Structure of Research in Organizational Behavior, 1972-1984: A Cocitation Analysis. J. Assoc. Inf. Sci. Technol. 1990, 41, 453-458. [CrossRef]

58. Inkpen, A.C.; Tsang, E.W.K. Social Capital, Networks, and Knowledge Transfer. Acad. Manag. Rev. 2005, 30, 146-165. [CrossRef]

59. Subramaniam, M.; Youndt, M.A. The influence of Intellectual Capital on the types of Innovative Capabilities. Ind. Manag. Data Syst. 2016, 116, 622-645. [CrossRef]

60. Bansal, P. Evolving sustainably: A longitudinal study of corporate sustainable development. Strateg. Manag. J. 2005, 26, 197-218. [CrossRef]

61. Matten, D.; Crane, A. Corporate Citizenship: Towards an Extented Theoretical Conceptualization. Acad. Manag. Rev. 2005, 30, 166-179. [CrossRef]

62. Carney, M. Corporate Governance and Competitive Advantage in Family-Controlled Firms. Entrep. Theory Pract. 2005, 29, 249-265. [CrossRef]

63. Giuliani, E.; Bell, M. The micro-determinants of meso-level learning and innovation: Evidence from a Chilean wine cluster. Res. Policy 2005, 34, 47-68. [CrossRef]

64. Faems, D.; Van Looy, B.; Debackere, K. Interorganizational collaboration and innovation: Toward a portfolio approach. J. Prod. Innov. Manag. 2005, 22, 238-250. [CrossRef]

65. Moran, P. Structural vs. relational embeddedness: Social capital and managerial performance. Strateg. Manag. J. 2005, 26, 1129-1151. [CrossRef]

66. Sampson, R.C. R\&D Alliances \& Firm Performance: The Impact of Technological Diversity and Alliance Organization on Innovation. SSRN Electron. J. 2005, 50, 364-386. [CrossRef]

67. Nuij, R. Eco-innovation: Helped or hindered by Integrated Product Policy. J. Sustain. Prod. Des. 2001, 1, 49-51. [CrossRef]

68. do Adro, F.J.N.; Leitão, J.C.C. Leadership and organizational innovation in the third sector: A systematic literature review. Int. J. Innov. Stud. 2020, 4, 51-67. [CrossRef]

69. Dias, C.S.L.; Rodrigues, R.G.; Ferreira, J.J. What's new in the research on agricultural entrepreneurship? J. Rural Stud. 2019, 65, 99-115. [CrossRef]

70. van Eck, N.J.; Waltman, L. Visualizing Bibliometric Networks; Springer International Publishing: Cham, Switzerland, 2014; ISBN 9783319103778.

71. Tzabbar, D.; Margolis, J. Beyond the startup stage: The founding team's human capital, new venture's stage of life, founder-CEO duality, and breakthrough innovation. Organ. Sci. 2017, 28, 857-872. [CrossRef]

72. Colombo, M.G.; Grilli, L. Founders' human capital and the growth of new technology-based firms: A competence-based view. Res. Policy 2005, 34, 795-816. [CrossRef]

73. Rauch, A.; Frese, M.; Utsch, A. Effects of human capital and long-term human resources development and utilization on employment growth of small-scale businesses: A causal analysis. Entrep. Theory Pract. 2005, 29, 681-698.

74. Podmetina, D.; Volchek, D.; Dąbrowska, J.; Fiegenbaum, I. Human resource practices and open innovation. Int. J. Innov. Manag. 2013, 17, 1340019. [CrossRef]

75. Hayton, J.C.; Zahra, S.A. Venture team human capital and absorptive capacity in high technology new ventures. Int. J. Technol. Manag. 2005, 31, 256-274. [CrossRef]

76. Barrena-Martínez, J.; Cricelli, L.; Ferrándiz, E.; Greco, M.; Grimaldi, M. Joint forces: Towards an integration of intellectual capital theory and the open innovation paradigm. J. Bus. Res. 2020, 112, 261-270. [CrossRef]

77. Martin, B.C.; Mcnally, J.J.; Kay, M.J. Journal of Business Venturing Examining the formation of human capital in entrepreneurship: A meta-analysis of entrepreneurship education outcomes. J. Bus. Ventur. 2013, 28, 211-224. [CrossRef]

78. Crook, T.R.; Todd, S.Y.; Combs, J.G.; Woehr, D.J. Does Human Capital Matter? A Meta-Analysis of the Relationship Between Human Capital and Firm Performance. J. Appl. Psychol. 2011, 96, 443-456. [CrossRef] [PubMed]

79. Berry, C.R.; Glaeser, E.L. The divergence of Human Capital levels across cities. Natl. Bur. Econ. Res. 2005, 84, 404-444.

80. Vandenbussche, J. Growth, Distance to Frontier and Composition of Human Capital. CEPR Discuss. Pap. 2005, 4860. 
81. Wood, D.J. Measuring corporate social performance: A review. Int. J. Manag. Rev. 2010, 12, 50-84. [CrossRef]

82. Shu, P.G.; Chiang, S.J. The impact of corporate governance on corporate social performance: Cases from listed firms in Taiwan. Pacific Basin Financ. J. 2020, 61, 101332. [CrossRef]

83. Stam, W.; Elfring, T. Entrepreneurial orientation and new venture performance: The moderating role of network types. Acad. Manag. J. 2008, 51, 97-111. [CrossRef]

84. Stam, W.; Arzlanian, S.; Elfring, T. Social capital of entrepreneurs and small firm performance: A meta-analysis of contextual and methodological moderators. J. Bus. Ventur. 2014, 29, 152-173. [CrossRef]

85. Acquaah, M. Managerial social capital, strategic orientation, and organizational performance in an emerging economy. Strateg. Manag. J. 2007, 28, 1235-1255. [CrossRef]

86. Hull, C.; Rothenberg, S. Firm performance: The interactions of corporate social performance with innovation and industry differentiation. Strateg. Manag. J. 2008, 29, 781-789. [CrossRef]

87. Orazalin, N.; Baydauletov, M. Corporate social responsibility strategy and corporate environmental and social performance: The moderating role of board gender diversity. Corp. Soc. Responsib. Environ. Manag. 2020, 27, 1664-1676. [CrossRef]

88. Delmas, M.; Hoffmann, V.H.; Kuss, M. Under the tip of the iceberg: Absorptive capacity, environmental strategy, and competitive advantage. Bus. Soc. 2011, 50, 116-154. [CrossRef]

89. Patton, D. Realising potential: The impact of business incubation on the absorptive capacity of new technology-based firms. Int Small Bus. J. Res. Entrep. 2014, 32, 897-917. [CrossRef]

90. Qian, H.; Acs, Z.J. An absorptive capacity theory of knowledge spillover entrepreneurship. Small Bus. Econ. 2013, 40, 185-197. [CrossRef]

91. Engelman, R.M.; Fracasso, E.M.; Schmidt, S.; Zen, A.C. Intellectual capital, absorptive capacity and product innovation. Manag. Decis. 2017, 55, 474-490. [CrossRef]

92. Debrulle, J.; Maes, J.; Sels, L. Start-up absorptive capacity: Does the owner's human and social capital matter? Int. Small Bus. J. 2014, 32, 777-801. [CrossRef]

93. Pereira, D.; Leitão, J. Absorptive capacity, coopetition and generation of product innovation: Contrasting Italian and Portuguese manufacturing firms. Int. J. Technol. Manag. 2016, 71, 10-37. [CrossRef]

94. Korunka, C.; Kessler, A.; Frank, H.; Lueger, M. Personal characteristics, resources, and environment as predictors of business survival. J. Occup. Organ. Psychol. 2010, 83, 1025-1051. [CrossRef]

95. Gately, C.G.; Cunningham, J.A. Building intellectual capital in incubated technology firms. J. Intellect. Cap. 2014, 15, 516-536. [CrossRef]

96. Hepworth, W.E. Practical Experiences with the Morgensen Sizer and Current Design Trends. Symp. Ser. Australas. Inst. Min. Metall. 1982, 17, 49-56.

97. Todeva, E.; Knoke, D. Strategic alliances and models of collaboration. Manag. Decis. 2005, 43, 123-148. [CrossRef]

98. Hewitt-Dundas, N. The role of proximity in university-business cooperation for innovation. J. Technol. Transf. 2013, 38, 93-115. [CrossRef]

99. Feng, H.I.; Chen, C.S.; Wang, C.H.; Chiang, H.C. The role of intellectual capital and university technology transfer offices in university-based technology transfer. Serv. Ind. J. 2012, 32, 899-917. [CrossRef]

100. Swamidass, P.M. University startups as a commercialization alternative: Lessons from three contrasting case studies. J. Technol. Transf. 2013, 38, 788-808. [CrossRef]

101. Organisation for Economic Co-Operation and Development. The Knowledge Based Economy; General Distribution Ocde: Paris, France, 1996.

102. Fioravanti, V.L.S.; Stocker, F.; Macau, F. Knowledge transfer in technological innovation clusters. Innov. Manag. Rev. 2021; ahead-of- $p$. [CrossRef]

103. Hsu, D.; Shen, Y.; Yuan, B.; Chou, C. Toward successful commercialization of university technology: Performance drivers of university technology transfer in Taiwan. Technol. Forecast. Soc. Chang. 2015, 92, 25-39. [CrossRef]

104. M'Chirgui, Z.; Lamine, W.; Mian, S.; Fayolle, A. University technology commercialization through new venture projects: An assessment of the French regional incubator program. J. Technol. Transf. 2018, 43, 1142-1160. [CrossRef]

105. Ahmad, A.J.; Ingle, S. Relationships matter: Case study of a university campus incubator. Int. J. Entrep. Behav. Res. 2011, 17, 626-644. [CrossRef]

106. Eveleens, C.P.; van Rijnsoever, F.J.; Niesten, E.M.M.I. How network-based incubation helps start-up performance: A systematic review against the background of management theories. J. Technol. Transf. 2017, 42, 676-713. [CrossRef]

107. Bruneel, J.; Ratinho, T.; Clarysse, B.; Groen, A. The evolution of Business incubators: Comparing demand and supply of business incubation services across different incubator generations. Technovation 2012, 32, 110-121. [CrossRef]

108. McAdam, M.; McAdam, R. High tech start-ups in University Science Park incubators: The relationship between the start-up's lifecycle progression and use of the incubator's resources. Technovation 2008, 28, 277-290. [CrossRef]

109. Nicholls-Nixon, C.L.; Valliere, D. A Framework for Exploring Heterogeneity in University Business Incubators. Entrep. Res. J. 2019, 10, 20180190. [CrossRef]

110. Tamásy, C. Rethinking technology-oriented business incubators: Developing a robust policy instrument for entrepreneurship, innovation, and regional development? Growth Chang. 2007, 38, 460-473. [CrossRef] 
111. Mas-Verdú, F.; Ribeiro-Soriano, D.; Roig-Tierno, N. Firm survival: The role of incubators and business characteristics. J. Bus. Res. 2015, 68, 793-796. [CrossRef]

112. Schwartz, M. A control group study of incubators' impact to promote firm survival. J. Technol. Transf. 2013, 38, 302-331. [CrossRef]

113. Avnimelech, G.; Schwartz, D.; Bar-El, R. Entrepreneurial high-tech cluster development: Israel's experience with venture capital and technological incubators. Eur. Plan. Stud. 2007, 15, 1181-1198. [CrossRef]

114. Ratinho, T.; Henriques, E. The role of science parks and business incubators in converging countries: Evidence from Portugal. Technovation 2010, 30, 278-290. [CrossRef]

115. Salvador, E. Are science parks and incubators good "brand names" for spin-offs? The case study of Turin. J. Technol. Transf. 2011, 36, 203-232. [CrossRef]

116. Mian, S.A. Assessing value-added contributions of university technology business incubators to tenant firms. Res. Policy 1996, 25, 325-335. [CrossRef]

117. Brown, R.; Mawson, S.; Lee, N.; Peterson, L. Start-up factories, transnational entrepreneurs and entrepreneurial ecosystems: Unpacking the lure of start-up accelerator programmes. Eur. Plan. Stud. 2019, 27, 885-904. [CrossRef]

118. Westhead, P.; Batstone, S. Independent Technology-based Firms: The Perceived Benefits of a Science Park Location. Urban Stud. 1998, 35, 2197-2219. [CrossRef]

119. Soetanto, D.P.; Jack, S.L. Business incubators and the networks of technology-based firms. J. Technol. Transf. 2013, 38, $432-453$. [CrossRef]

120. Schwartz, M.; Hornych, C. Cooperation patterns of incubator firms and the impact of incubator specialization: Empirical evidence from Germany. Technovation 2010, 30, 485-495. [CrossRef]

121. Macpherson, A.; Holt, R. Knowledge, learning and small firm growth: A systematic review of the evidence. Res. Policy 2007, 36, 172-192. [CrossRef]

122. Rubin, T.H.; Aas, T.H.; Stead, A. Knowledge flow in Technological Business Incubators: Evidence from Australia and Israel. Technovation 2015, 41-42, 11-24. [CrossRef]

123. Barbero, J.L.; Casillas, J.C.; Wright, M.; Ramos Garcia, A. Do different types of incubators produce different types of innovations? J. Technol. Transf. 2014, 39, 151-168. [CrossRef]

124. Wyllie, J.; Skyrme, D.J.; Lelic, S. Taxonomies: Frameworks for Corporate Knowledge: The Shape of Things to Come? Ark Group: London, UK, 2003; ISBN 0954389719. 